Meta

Journal des traducteurs

Translators' Journal

\title{
Linguistic Characteristics and Interpretation Strategy Based on EVS Analysis of Korean-Chinese, Korean-Japanese Interpretation
}

\section{Hye-Rim Kim}

Volume 50, numéro 4, décembre 2005

Pour une traductologie proactive - Actes

For a Proactive Translatology — Proceedings

Por una traductología proactiva - Actas

URI : https://id.erudit.org/iderudit/019846ar

DOI : https://doi.org/10.7202/019846ar

Aller au sommaire du numéro

Éditeur(s)

Les Presses de l'Université de Montréal

ISSN

0026-0452 (imprimé)

1492-1421 (numérique)

Découvrir la revue

Citer cet article

Kim, H.-R. (2005). Linguistic Characteristics and Interpretation Strategy Based on EVS Analysis of Korean-Chinese, Korean-Japanese Interpretation. Meta, 50(4). https://doi.org/10.7202/019846ar

\section{Résumé de l'article}

Une analyse comparative des résultats de l'estimation EVS d'une interprétation simultanée coréen-japonais, deux langues similaires au niveau syntaxique et d'une seconde coréenchinois dont les syntaxes sont différentes a permis d'étudier la corrélation entre les caractéristiques linguistiques et les stratégies d'interprétation : l'interprète qui a travaillé en coréen et chinois a adopté comme stratégie de suivre de très près l'orateur tandis que celui qui a travaillé en coréen et japonais a pris du temps avant de commencer son interprétation ne recourant pas uniquement à des repères grammaticaux. Ainsi, le processus de traitement de l'information au cours de l'interprétation simultanée ne repose pas sur les caractéristiques syntaxiques inhérentes aux langues mais sur l'unité de sens et se réalise avec succès par l'anticipation et par l'expérience acquise par l'interprète. 


\title{
Linguistic Characteristics and Interpretation Strategy Based on EVS Analysis of Korean-Chinese, Korean- Japanese Interpretation
}

\author{
HYE-RIM KIM \\ Ewha Womans University, Seoul, Korea \\ hyerim@ewha.ac.kr
}

\section{RÉSUMÉ}

Une analyse comparative des résultats de l'estimation EVS d'une interprétation simultanée coréen-japonais, deux langues similaires au niveau syntaxique et d'une seconde coréenchinois dont les syntaxes sont différentes a permis d'étudier la corrélation entre les caractéristiques linguistiques et les stratégies d'interprétation : l'interprète qui a travaillé en coréen et chinois a adopté comme stratégie de suivre de très près l'orateur tandis que celui qui a travaillé en coréen et japonais a pris du temps avant de commencer son interprétation ne recourant pas uniquement à des repères grammaticaux. Ainsi, le processus de traitement de l'information au cours de l'interprétation simultanée ne repose pas sur les caractéristiques syntaxiques inhérentes aux langues mais sur l'unité de sens et se réalise avec succès par l'anticipation et par l'expérience acquise par l'interprète.

\footnotetext{
ABSTRACT

This study was stimulated by several questions: What time lag is contained in the synchronicity of simultaneous interpretation? How do the linguistic characteristics of the language to be interpreted influence synchronicity? And in what is the interpreter's strategy for achieving synchronicity in interpretation from Korean to other languages? To answer these questions, EVS measurements of Korean-Japanese and Korean-Chinese interpretation materials were analyzed. The results showed that in Korean-Chinese interpretation the interpreter begins the interpretation before a whole sentence is finished, and that in Korean-Japanese interpretation, the interpreter leaves a time lag before beginning the interpreted utterance. This study indicated that the information processing in simultaneous interpretation is not carried out through the characteristics of the language itself but the interpreter's guessing based on unit of meaning and strategies accumulated by the interpreter through long experience.
} 


\section{MOTS-CLÉS/KEYWORDS}

linguistic characteristics, interpretation strategy, synchronicity, EVS analysis, unit of meaning

\section{Introduction}

In June 2004 the Asia Trustworthy Computing Council conference was held in Seoul. ${ }^{1}$ The relay method of interpretation was used at this conference on Trustworthy Computing strategy, the presentations being mostly made in English and interpreted into Korean and then into Chinese. Aside from the end users who had to rely solely on the interpretation provided, conference staff from the MS office in Singapore were also present at the event. Both end users and the staff were all specialists in the subject matter. At the end of the first day of the conference, the staff requested that the Chinese interpreter be replaced. ${ }^{2}$ Although the end users had expressed satisfaction with the interpretation, it was later revealed that the staff requested a change of interpreter for the following reason.

The staff, fluent in both English and Chinese, monitored the Chinese interpretation while the English presentations were being made. Overlooking the fact that the relay method of simultaneous interpretation was being used, they were not able to contain their anxiety over the time lag that occurred, which was longer than they had expected.

Generally, the greatest issue raised in regard to relay interpretation is accuracy of content. If the accuracy of interpretation, or coverage, is estimated to be 80 percent, then even if 80 percent coverage is achieved in the first stage of relay interpretation, this figure falls to 64 percent coverage of the original message in the second stage. But in the above example, considering that the end users expressed satisfaction with the interpretation and that smooth communication was achieved between the speaker and the listener, it can be said that time lag stood out as the problem in relay interpretation.

The 1995 survey by the $\mathrm{AIIC}^{3}$ shows that synchronicity is an important variable in evaluation of interpretation. ${ }^{4}$ Kurz (2001:204) also pointed out that synchronicity was one of the important variables pointed out by the respondents in a survey: "Synchronicity was one of the interviewees' main expectations. Long pauses and lagging behind the original were considered irritating."

Interpretation is the process of understanding content spoken in one language and expressing in another language. Therefore, interpretation that is completely simultaneous with the utterance of the speaker is fundamentally impossible. In addition, it is inevitable that the time lag in 
interpretation is longer than that in shadowing in the same language where no process of understanding is involved. ${ }^{5}$

This study is based on such questions as: How much time lag is there in the synchronicity of simultaneous interpretation? How do the linguistic characteristics of the language to be interpreted influence synchronicity? And what is the interpreter's strategy for achieving synchronicity in interpretation from Korean to other languages?

To answer these questions, I attempted an analysis of EVS measurements, which is one of the time lag variables, in simultaneous interpretation materials between Korean and Japanese which are syntactically similar, and between Korean and Chinese which are syntactically dissimilar. On the basis of this work, I then analyzed the relationship between linguistic characteristics and interpretation strategy.

\section{Body}

\subsection{Linguistic Characteristics}

Korean is an agglutinative language with SOV (subject-object-verb) word order, and a language where the grammatical form is made apparent through words indicating meaning or by attaching postpositions or affixes ${ }^{6}$ (Nam 2001: 23-34) which show the grammatical relationship between words. Word order is comparatively free in Korean, a discourse-based language where the topic ${ }^{7}$ plays an important role in determining the word order. (Park 1991)

Chinese is as an isolating language ${ }^{8}$ in which grammatical tagging is not well developed and the grammatical functions are revealed in the word order. It is also different to Korean in that it has a SVO (subject-verb-object) word order system (Norman 1996 : 25). However, both Korean and Chinese $^{9}$ are topic-based languages.

Korean and Japanese are categorized in the same family of languages and indeed they do have many similarities in terms of $\operatorname{syntax}^{10}$ (Byun 1993 : 831). In both Korean and Japanese the expression of honorifics (polite speech) is well developed but Japanese uses relative honorifics while Korean uses absolute honorifics, and this is very difficult to accurately convey through interpretation (BAEK, Dong-seon, pp.67-88).

Korean, Japanese and Chinese are all cultures that use Chinese characters ${ }^{11}$ in their written languages, which means both Japanese and Korean have many Chinese-character words. 


\subsection{Analysis}

EVS (ear-voice span) is the time lag between the moment the conference interpreter perceives the incoming message and the moment he/she produces the interpreted version ${ }^{12}$ and can be considered as the time taken to process information. Therefore, EVS is an important indicator of the interpreter's information processing procedure.

According to Barik (1973), the EVS is usually around 3 seconds and can be seen as the minimum time taken for the simultaneous interpretation model to start working.

\subsubsection{Materials and Procedures}

The materials used for analysis are original tape recordings of Korean to Chinese/Chinese to Korean, Korean to Japanese/Japanese to Korean, Chinese to Korean to Japanese, and Japanese to Korean to Chinese interpretation from the conference "Sectoral Implications of a China-JapanKorea FTA" held October 11, 2004. The interpreters were veterans with more than 10 years' experience who have interpreted on 500 to 1,000 occasions, and for the sake of unity of language the interpretations produced by two interpreters were sampled. The contents of the whole conference covering 7 hours were recorded but the sample that was used directly for EVS analysis was confined to the discussion at the end of the conference. This was done is in order to understand how linguistic variables that are conveyed only as sound signals, without the aid of text and Powerpoint presentations, influence the information processing of simultaneous interpretation. Because the success of question and answer session can be used as a standard to judge how successfully the interpreter has fulfilled the role of communication, and on the premise of successful communication, such materials are more objective for pure analysis of linguistic characteristics and interpretation strategy.

In this study, in contrast to the use of experimental materials to research the simultaneous interpretation process by Barik (1973), Goldman-Eisler (1972), and Gerver (1969), actual interpretation materials were analyzed. Though the importance of experimental material where many various variables can be controlled cannot be ignored, the advantage of using actual interpretation materials is that the differences from a real life situation that can occur when using experimental material can be reduced (Gile 1994:45). 
Looking at the analysis process, 1) first, a script is made of the selected sample (around 40 minutes long), 2) the sound signals are stored in the computer, 3) using sound analysis software, the EVS is measured and then using EXCEL this is turned into statistical data. For this study the software Sound Forge was used.

\section{Figure 1. EVS Measurement Using Sound Forge}

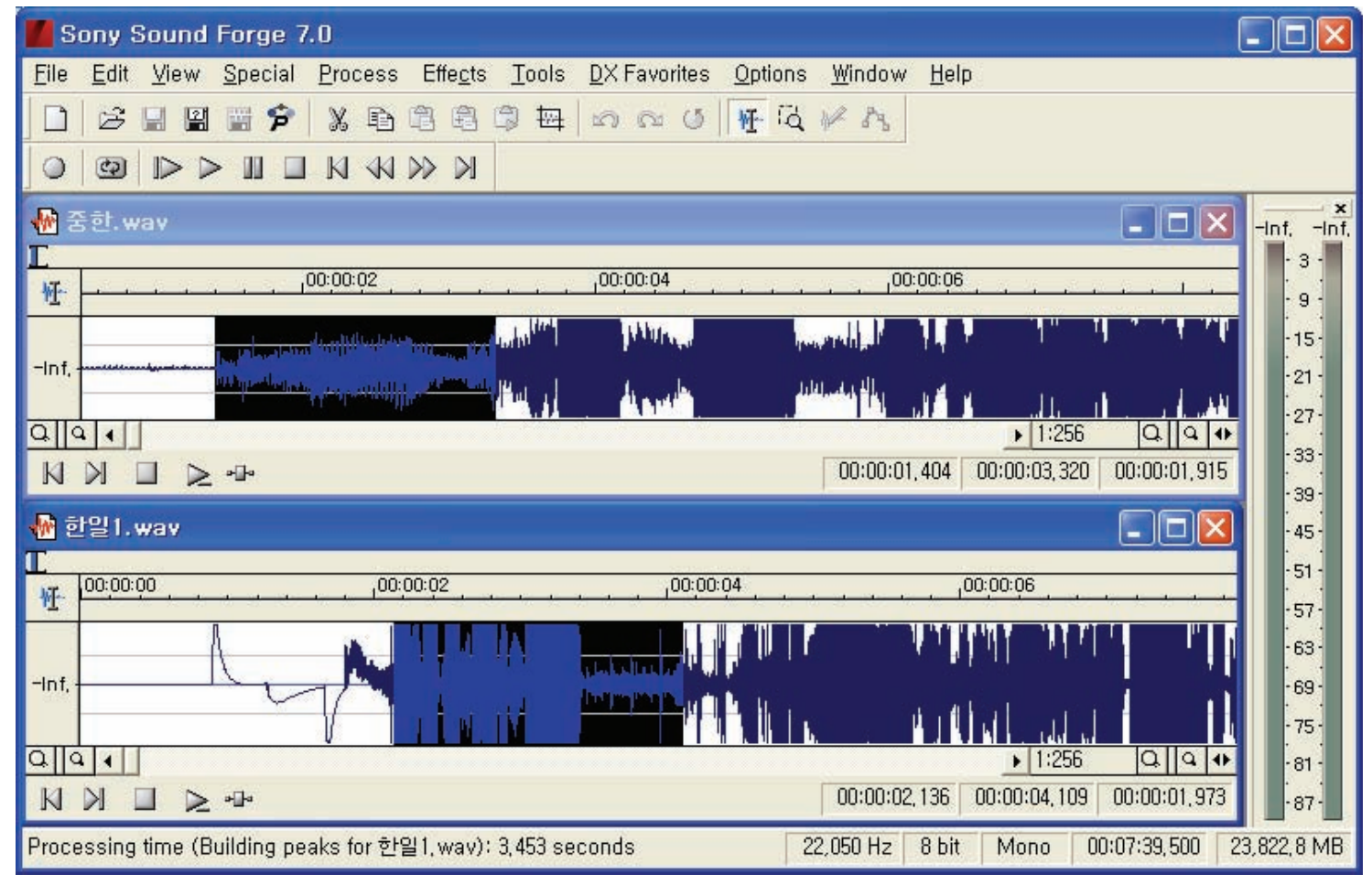

\subsubsection{Results}

The following graph shows the results of EVS measurement in Korean-Chinese and KoreanJapanese interpretation gained through analysis of real interpretations. 


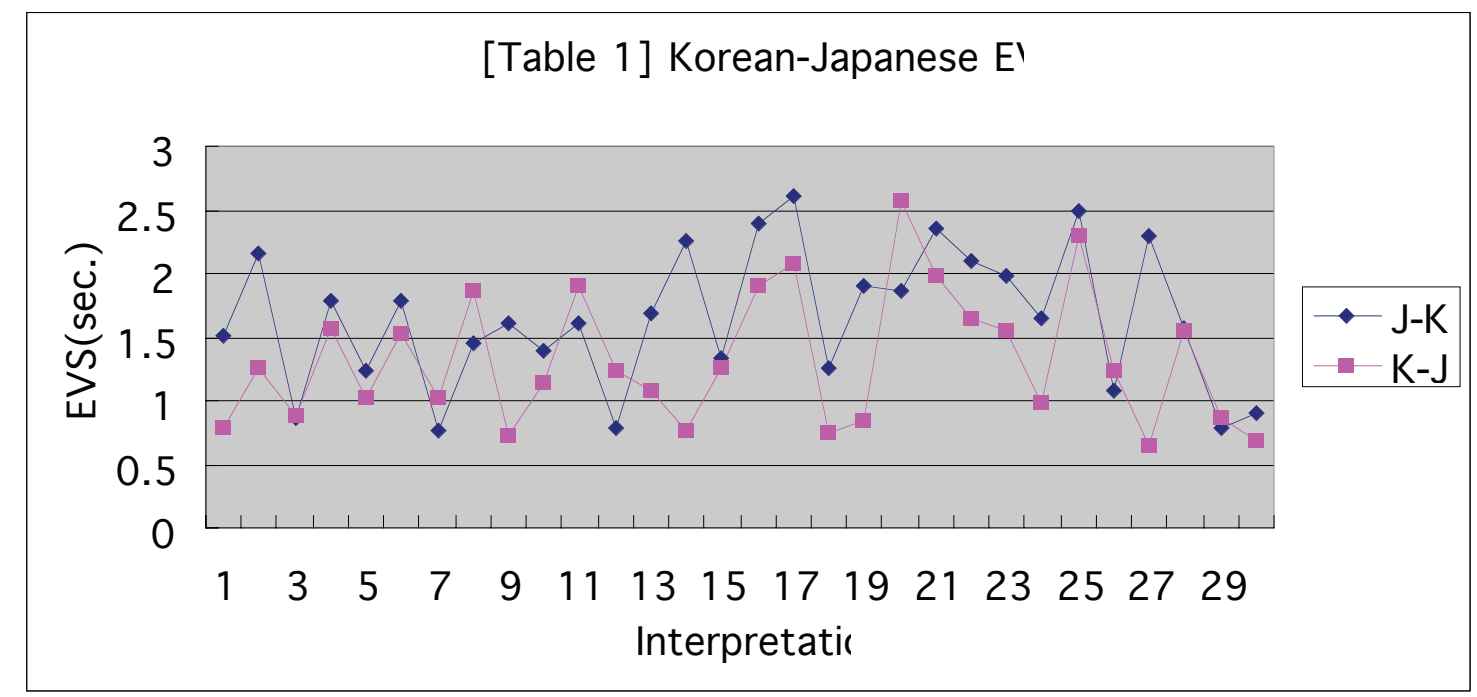

The overall average was 1.648 seconds from Japanese to Korean, and 1.321 seconds from Korean to Japanese. But when excluding all the cases where the interpretation could be uttered immediately, or under one second, such as when the adverb indicating tense appears at the beginning of the sentence or when conjunctions make it unnecessary to divide into units of meaning, then the average was 1.851 seconds for Japanese to Korean and 1.584 for Korean to Japanese.

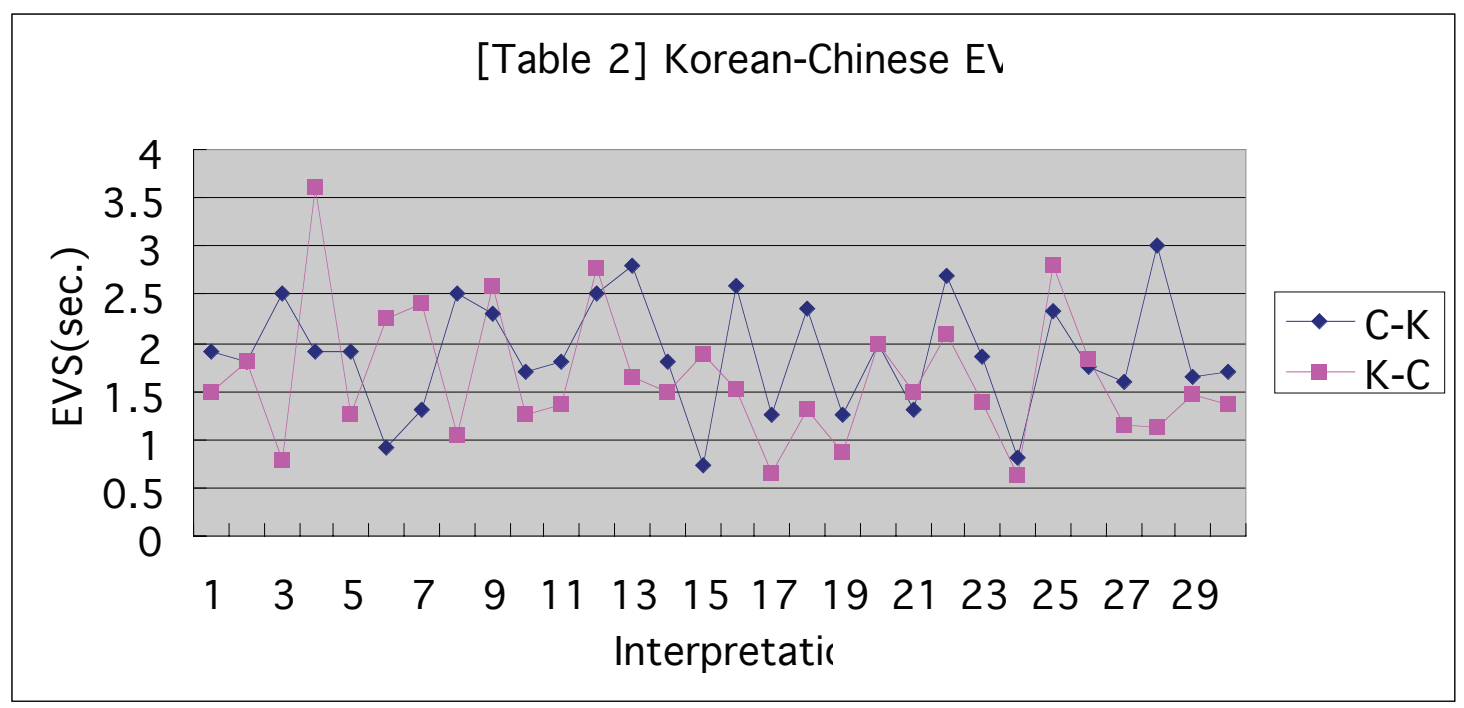

The overall average was 1.885 seconds for Chinese to Korean, and 1.642 for Korean to Chinese. 
But when excluding all the cases where the interpretation could be uttered immediately, or under one second, such as when the adverb indicating tense appears at the beginning of the sentence or when conjunctions make it unnecessary to divide into units of meaning, then the average was 2.003 seconds for Chinese to Korean, and 1.782 seconds for Korean to Chinese.

It is interesting to note that, contrary to expectations, although the syntactic systems and linguistic characteristics of the two pairs of languages are different, the EVS moved within a similar range of error. That is, the EVS measurements between Korean and Chinese, which have different linguistic characteristics, are not so different to those between Korean and Japanese, which are of the same family of languages and have the same word order, and where the meaning in sentences is indicated by postpositional words. As can be seen in the table below, the EVS figures are similar, with differences in the range of $0.2-0.3$ seconds.

Table 3. Comparison of Korean-Chinese/Korean-Japanese EVS Measurements

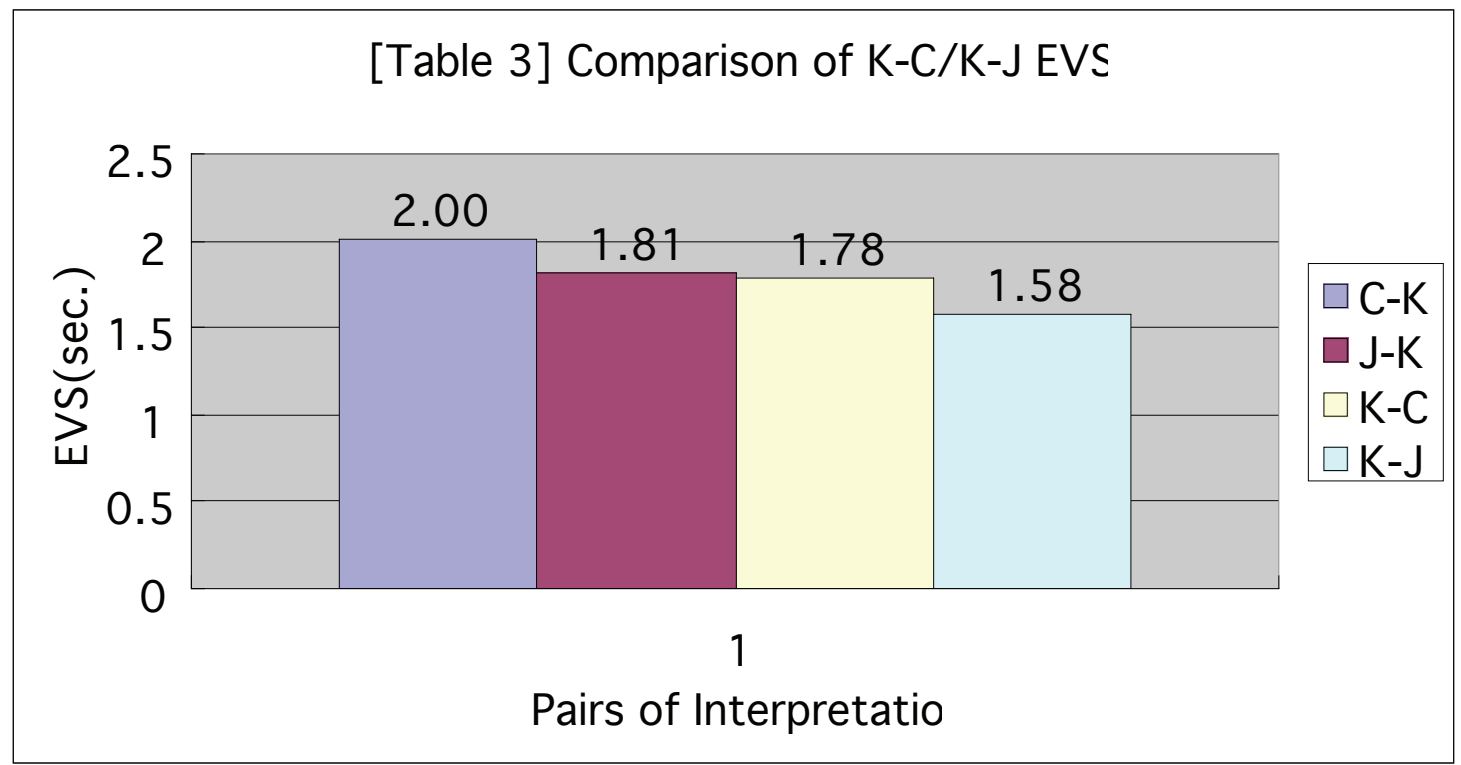

\subsection{Linguistic Characteristics and Interpretation Strategy Seen Through EVS Measurement}

The linguistic characteristics of Korean, Chinese and Japanese languages might lead one to estimate a big difference, of at least one second, in EVS measurements between the interpretation pairs of Korean-Chinese and Korean-Japanese. 
But results of analysis of the actual data showed that, contrary to expectations, the EVS measurements were similar between the two pairs of languages, and the 0.2 seconds extracted was a very small difference within the range of error and therefore not significant.

These results show that in interpretation between Korean and Chinese, which have different word order, the interpreter adopts the strategy of following close on the heels of the original utterance. On the other hand, with interpretation between Korean and Japanese, which have the same word order and where grammatical meaning is indicated through changes in postpositions and affixes the interpreter, rather than following close on the heels of the speaker based on grammatical tagging, leaves a time lag before beginning the interpreted utterance.

Analysis of an actual text interpreted from Korean to Chinese reveals the following facts.

Ex. 1) 그래서 전자회사 입장에서 보면은 어떤 경쟁 축, 제가 말씀 드린 두 개

축, 이 두 개 축의 어느 한 분야에 속한다 하더라도 항상 해외 여러 가지 기업, 해외 의 여러 가지 룰 이런 규제의 제약을 받거나 규제를 우리가 준수를 하면서 기업 활 동을 전개해 나가지 않으면 안 되는 것이죠.

[Geuraeseo jeonjahoesa ipjangeseo bomyeoneun eotteon gyeongjaengchuk, jega malsseum deurin dugaechuk, idugechukui eoneu han bunyae sokhanda hadeorado hangsang haeoe yeoreogaji gieop, haeoeui yeoreogaji rul ireon gyujeui jeyakeul batgeona gyujereul uriga junsureul hamyeonseo gieop hwaldongeul jeongaehae nagaji aneumyeon andoeneun geotijyo.]

$\rightarrow$ 所以对电子公司来, 立场来看的话, 某一个竞争的主轴呢, 刚才我谈过的两个 轴, 虽然属于其中的一个轴，在海外的任何企业、海外的各种规则或者是限制呢， 会受到这样子的限制。我们必须要遵守这样子的限制来展开我们的企业活动。不遵 守是不行的。

(Therefore, seen from the viewpoint of an electronics company a certain competition axis, the two axes that I have mentioned, even if [the company] belongs to one of these fields, the various overseas businesses are always restricted by various overseas rules, and we cannot carry out business activity without obeying those rules. We have no choice but to obey the rules.)

First, there is a tendency for the interpreter, based on the initial information in the sentence, to guess the sentence structure and overall message and begin interpretation. These results coincide with the research results by Lee Tae-hyung on time analysis of the simultaneous interpretation process of between English and Korean, which have differing syntactic structures and word order. ${ }^{13}$ If we look at Example 1) the source text's (ST) predicate is “전개해 나가지 않으면 안 되는 것이죠" (cannot carry out business activity without obeying those rules.) That is, in Korean the verb appears at the end of the sentence. So if one waits endlessly for the verb to come a great gap may appear in the interpretation, which means that the interpreter would have to remember too much information. This kind of difficulty leads the interpreter to begin interpretation after guessing the overall message based on initial information. As a result, there is a tendency for expression in the Chinese target text (TT) to be cut into many short sentences, which means the predicate of the sentence is often repeated again in the latter part of the interpretation. 
In contrast, in Chinese the verb, the core of the sentence, comes at the beginning and the end users, as seen in their information processing procedure, can early on guess the structure of the sentence the speaker is composing. In other words, the predictability of sentence structure and content is somewhat higher. ${ }^{14}$ Therefore, the interpreter guesses the structure of the overall sentence indicated by the verb and makes the utterance after naturally connecting it to the predicate and for this reason the EVS is longer in Chinese to Korean than in Korean to Chinese. ${ }^{15}$ But even in the direction of Chinese to Korean, the strategy of interpreting the verb first is often used.

Ex. 2) 但我个人来讲, 更令人忧虑的是, 不仅仅是电子行业, 而且是其他行业, 举 个例子来说, 一般机械, 汽车行业, 可能面临问题, 这个负面的影响可能很大。 [Danwogerenlaijiang, genglingren youlvdeshi, bujinjinshi dianzihangye, erqieshi qitahangye, jugelizilaishuo, yibanjixie, qichehangye, kenengmianlinwenti,

zhegefumiandeyingxiang kenenghenda.]

$\rightarrow$ 제 개인적으로 생각할 때 더욱 더 우려하는 것은 전자 업종뿐만 아니라 다른 업 종, 예를 들어 어 그러니까 일반 기계류라던가 자동차업종이 그 마이너스 효과가 굉 장히 클 것이다 라는 것을 우려하지 않을 수 없습니다.

(In my personal opinion, the greater concern is that not only in the electronics industry but also other industries such as machines or automobiles, the negative effect will be great, and this cannot but be a matter of concern.)

The above can be seen to result of the simultaneous interpreter, who is inevitably burdened by the task of information processing when the predicate becomes too long, acting on certain automatic know-how.

Second, the above example shows that the TT is written in the topic-comment structure. Kang Ji-hye's (2001) analysis of actual English to Korean simultaneous interpretation showed that the interpreter tended to compose the utterance in the topiccomment structure. If English is a subject-based language, Korean is a topic-based language. Therefore, in interpretation from English to Korean the interpreter uses the topiccomment structure and thus maintains the connection between the prior and latter discourse. In this way the interpreter not only achieves economy of expression but also adjusts the word order and minimizes the formation of non-grammatical sentences. As mentioned in part 2.1 on Linguistic Characteristics, both Korean and Chinese are topic-based languages. Therefore, whether it is Korean to Chinese interpretation or Chinese to Korean, the topiccomment structure is often found in the TT in both directions.

According to psycholinguistic research, the speaker is able to more rapidly and more easily make topic-based utterance. In Korean, the postpositional words attached to nouns play a very important role in dismantling syntax and it is said that sentences where the topic is indicated with "는[neun]" are easier to understand than sentences where the case marker "가[ga]" is used. In addition, research on topic and memory shows that memory regarding topic is sustained for a relatively long time and there is no overload in information processing in moving from memory to utterance, but memory regarding language form is relatively short in comparison. ${ }^{16}$

It can be observed in both directions of Korean-Chinese interpretation that to compose the sentence the interpreter selects the topic word considering the context of the earlier part of the sentence and based on this topic word guesses the comment from the core 
content of the speaker's utterance. In "linguistic knowledge", which forms an important standard framework for guessing, the discourse topic and verb play an important role. When the interpreter composes the utterance from guessing and inference and conveys it to the end users, he/she tries to use a structure of meaning that is highly related to the overall topic of the original text and connects with the prior context. Also, to overcome difference in word order the message recomposed from guessing is made up of several short sentences and the interpreter tries to connect these several short messages to the topic to convey a unified single comment. Therefore, in Korean-Chinese interpretation where there is a definite difference in word order, the topic-comment structure is very often used.

Third, it can be confirmed that the difficulty of information processing concerning linguistic structure is overcome by using non-linguistic information and interpretation is achieved with short EVS. In actual interpretation, the interpreter anticipates the overall message before concrete linguistic information is accurately inputted.

Ex. 3) 그러니깐 어 제가 이번의 이 회의를 통해서, 저는 전혀 아카데믹한 분야의 사 람이 아닙니다만, 여러분들의 여러 가지 의견을 듣고 이 한중일 3 국의 FTA는 가능 하면 조속히 체결이 되기를 바랍니다.

[geureonikkan eo jega ibeonui I hoeuireul tonghaeseo, jeoneun jeonhyeo akademikhan bunyaui sarami animnidaman, yeoreobundeului yeoreo gaji uigyeoneul deutgo I hanjungil samgukui FTAneun ganeunghamyeon josokhi chegyeoli doegireul baramnida.] $\rightarrow$ 那么, 我希望通过这次会议呢, 我并不是这个学术界的专业人士, 我听了很多 的意见之后呢, 对中日韩三国的FTA尽可能的, 我想快速地越早建立越好。我祈愿 这样子。

(Therefore, I hope, through this conference, although I am not from an academic field, after hearing everyone's various opinions, the Korea-Japan-China FTA will be concluded as soon as possible, I hope.)

In this case, the interpreter, based on circumstantial information in the text, interpreted the incomplete linguistic information within the already constructed framework and worked out in advance the message that the speaker wanted to convey. This shows that the experienced interpreter, through comprehensive analysis of the logic of the speaker's presentation, background knowledge, circumstantial information and other non-linguistic information, guesses the general direction and message of the speaker's speech.

Looking at Korean-Japanese linguistic characteristics and interpretation strategy, as already examined above, both Korean and Japanese are SOV languages that belong to the same language family in terms of language type. They also have the same grammatical structure in that they use grammatical markers such as postpositional words and affixes. In spite of this, the reason for the EVS measurements being as long as those found in interpretation between Korean and Chinese, which have different word order, can be found in the linguistic characteristics discussed below.

First, in Japanese the more high-level the expression becomes the greater the use of the passive form. If this were to be expressed without modification in the target language, Korean, the end users would find it very awkward to listen to and the relay interpreter in the next booth would also find it impossible to carry out immediate or smooth interpretation. 
Ex. 4) 本日は、○○会議が開催される運びとなりましたことを、まことに喜ばし く思います。[Honjitsuwa, ookaigiga kaisaisareru hakobito narimashita kotowo, makotoni yorokobashiku omoimasu.]

$\rightarrow$ 오늘 $\mathrm{OO}$ 회의의 개최를 진심으로 축하드립니다.

(On the opening of XX conference today, I extend my sincere congratulations.)

Second, because the expression of polite language is used differently in Korean and Japanese this places a burden on the cognitive function of the simultaneous interpretation process, which calls for instant processing.

Ex. 5) 오늘 마지막 세션에서 토론에 참석해 주실 분은 여섯 분이고, 각 나라 당 두 분씩입니다. [oneul majimak saesyeoneseo torone chamseokhae jusil buneun yeoseot bunigo, gak naradang du bunssikimnida.]

てえ、最後のセッションで、討論に、元、ご参加なさる先生方は六人いらっしゃ います。元、各国別に二方ずつお招きいたしました。

(Um, in the final discussion today, um, six people will be participating, um, two from each country.)

In this case, when the Korean is interpreted into Japanese, the interpreter has cut the sentences with "um" in between, as can be seen in the English translation. This shows the interpreter's attempt to correctly express the polite language.

Third, because of the unique ambiguity of the Japanese language logic it is difficult in the process of expression in the target language to accurately reflect in the TT the level and intensity of expression called for in the ST.

Ex. 6) 従いまして、私が、何度も繰り返し申し上げ申し訳ありませんが、例えば 私の会社も70以上の国で私は企業活動を展開しております。[Shitagaimasite,

watakushiga, nandomo kurikaeshi moushiage moushiwakearimasenga, tatoeba watakushino kaishamo nanaju ijyouno kunide watakushiwa kigyoukatsudouwo tennkaishite orimasu.]

$\rightarrow$ 그래서 에 제가 수 차례 거듭 말씀 드려서 죄송합니다마는, 예를 들어서 저희 후 지쓰 같은 경우에도 70 개 이상의 국가들에서 저희가 기업 활동을 전개하고 있습니 다.

(Therefore, I apologize for repeating this over and over, but for example, in the case of our company, Fujitsu, we are doing business in more than 70 countries.)

The above example shows that whereas the original text mentions "our company", the interpreter has expressed this as "in the case of our company Fujitsu". This can be seen as the experienced interpreter's strategy to clearly convey the logical structure of the target text.

Fourth, as pointed out by Kim Han-sik (1999), though there are cases when Chinese character words are simply transformed into the pronunciation of the same characters in the 
target language to achieve interpretation, when such transformation of pronunciation is attempted as an automatic reflex, there is the possibility of failure to convey the right meaning because of differences in words using the same Chinese characters or inaccuracy of pronunciation. ${ }^{17}$

Ex. 7) 例えば我々の会社のみならず日本の電子産業が、何か寄与できることがあ れば、色々なネットワーク、ルーツを通じてお話ください。いつでも我々は協力 する可能性があります。[Tatoeba, warewareno kaisha nominarazu nihonno denshisangyouga, nanika kiyo dekirukotoga areba, iroirona nettowa-ku, ru-tsuwo tsujite ohanashikudasai. Itsudemo warewarewa kyouryokusuru kanouseiga arimasu.] $\rightarrow$ 그래서 앞으로 뭔가, 예를 들어서 저희 회사뿐만 아니라 일본의 전자산업이 문 가 기여 할 수 있는 일이 있으면, 여러 가지 네트워크, 루트를 통해서 애기를 해주시 기 바랍니다. 언제든지 저희들은 협조할 가능성이, 여지가 있습니다.

(So in the future, not only our company but also if there is anything that the Japanese electronics industry can contribute, we hope that you will let us know through various networks and routes. There is always the possibility, the room for cooperation.)

In Ex. 7) when the interpreter first came across the word “可能性” in the source text he/she first translated it as "possibility" but then decided "room" was a better translation and made the correction. This kind of correction often occurs in Korean-Chinese interpretation ${ }^{18}$

The longer-than-expected EVS in Korean-Japanese interpretation arises because it is relatively easy for the interpreter to understand the meaning based on clear grammatical markers such as postpositional words and affixes, and therefore begins the utterance after examining all the above mentioned elements. This can be seen as the result of the experienced interpreter's automatized know how in appropriately adjusting diverse information processing without burdening the short-term memory.

The EVS is shorter in Korean to Japanese interpretation rather than Japanese to Korean because the interpreter adopts the strategy of reducing the time taken for information processing and allotting more time for utterance because, Japanese requires more syllables than Korean to convey the same volume of information. So when interpreting Korean into Japanese the interpreter tends to speed up the utterance because of the burden of uttering more syllables.

Of course, the volume of information processing at each stage can be changed by several variables. In particular when the ST is of a complex structure, or when the content is highly specialized, or when the pronunciation of the speaker is difficult to understand, then greater processing capacity is required.

Aside from the actual variables mentioned above, this study has examined interpretation strategy based on the influence of linguistic characteristics on the simultaneous interpretation process. Through this work, the author could confirm that the experienced interpreter uses several methods to solve problems and carry out smooth simultaneous interpretation. 


\section{Conclusion}

In the above study the author was able to confirm that the information processing in simultaneous interpretation, where expression follows understanding, is not carried out through the grammatical characteristics of the language itself but the interpreter's intelligent estimation based on the unit of meaning and use of interpretation strategies accumulated over a long period of time.

Hence, the interpreter's strategies gained through experience should be reflected in the training of future interpreters. Through repetition based training in the interpretation strategy examined in the body of this paper, information processing ability can become automatic.

However, the difficulty of obtaining high quantity and adequate sampling data and the fact that the author is a Korean-Chinese interpreter with limited knowledge of Japanese, thus leading to weakness in the analysis, are points that must be reinforced in the future.

Toward that end, the author intends to continue sampling and increase the amount of data for analysis and attempt to carry out joint work with a Korean-Japanese interpreter and colleague. Experiments will be carried out with veteran interpreters to see what strategies they use to overcome linguistic characteristics and reflect the results in teaching methods. The advice and interest of other scholars would be welcome.

\section{NOTES}

1. The conference was organized by MS Korea and held over two days, June 14-15.

2. Evaluation of interpretation results is very strict in Korea. It may be carried out by a speci alist within the organizing party who is capable of monitoring interpretation in the language involved, or may be done through an immediate survey regarding the interpretation.

3. The International Association of Conference Interpreters

4. "Survey Expectation of Users of Conference Interpretation." The results showed that the users' expectations were faithfulness, synchronicity, rhetorical skills, voice, and feeling and naturalness. LIM, Hyang-ok (1999:150).

5. Refer to Gerver (1969)

6. By function, postpositions in Korean can be divided into case markers (which show the $\mathrm{r}$ elationship between a noun and predicate verb in a sentence) and auxiliary particles (which add special meaning.)

7. Research on the subject was carried out by scholars of the Prague School who say that th e speaker begins the sentence with the less informative elements. "Topic" is different from $t$ he general concept of "subject" in that the topic does not have a thematic role that is projecte $\mathrm{d}$ from the verb, and does not create an awkward sentence even if it is not semantically relat ed to the verb.

8. An isolating language where every word consists of a single morpheme and the grammat ical relationship is established by the word order.

9. CAO, Feng-fu (1995)

10. LEE (1989:5) pointed out the following similarities between Korean and Japanese: 1) s ame grammatical structure, 2) same word order, 3) no word begins with a sonant or the " $\mathrm{r}$ " sound, 4) vowel harmony, 5) same-type Chinese character words with the same meaning. 
11. Cultures that use Chinese characters refer to countries that use Chinese characters as a means of written expression. When Korea and Japan had no writing system of their own th ey adopted Chinese characters. After the invention of the Korean alphabet, Hangeul, Chines e characters and Hangeul can be used together or separately, while in Japan Chinese charact ers and Japanese characters must be used together.

12. The time between certain segments of the speaker was perceived by the interpreter and $t$ he time the interpreter produces his interpreted version; interpreters carry out concurrent pro cessing of comprehending, converting, planning and uttering TL. (LEE 2004)

13. This seems to be the interpreter's strategy not to lag too far behind the speaker. If he lag $\mathrm{s}$ too far behind, he has to store large amounts of information in his short-term memory whi ch will tax the whole processing system. (LEE 2004)

14. The verb plays a key role in the transmission of information in the structure of a sentenc e. Therefore, information coming from the verb plays an important part in grasping the who le sentence.

15. Goldman-Eisler (1972) pointed out that in 90-95 percent of cases the EVS consisted of at least one complete predicative expression.

16. KANG, Ji-hye, 2001.

17. KIM, Hye-rim (2004) also points out that there is language interference caused by Chin ese character words in the source text in simultaneous interpretation.

18. For example, “那么, 出口方面呢, 这几年连续几年呈显出大幅度的成长。” $\rightarrow$ 어 수출에 있어서도 어 몇 년 연속 대폭적인 성, 신장세를 보였습니다.” (In exports, for several years there has been a great growth, expansion.) 


\section{REFERENCES}

BARIK, H. C. (1973): "Simultaneous Interpretation: Temporal and Quantitative Data", Language and Speech 16-3, p. $237-270$.

BYun, G.. (1993): Collection of Major Languages of the World, and Major Languages and Literature I, Foreign Studies Research Institute, Hankuk University of Foreign Studies.

CAO, F. F. (1995): Function of the Topic in Translation, Yuwen Publishing.

CHOI, Y. (1998): What is the Chinese Language?, Tongnamu.

Gerver, D. (1969): “The Effects of Source Language Presentation Rate on the Performance of Simultaneous Conference Interpreters", The Interpreting Studies Reader, p. 52-66.

GILE, D. (1997): “Conference Interpreting as a Cognitive management problem”, The Interpreting Studies Reader, p. $163-176$.

GILE, D. (1994): "Methodological Aspects of Interpretation and Translation Research", In S. LAMBERT and B. MOSER-MERCER (Eds.), Bridging the Gap: Empirical Research in Simultaneous Interpretation, Amsterdam, John Benjamins.

GILE, D. (1995): Basic Concept and Models for Interpreter and Translator Training, Amsterdam, John Benjamins.

Goldman-EISLER, F. (1972): "Segmentation of Input in Simultaneous Translation", The Interpreting Studies Reader, p. 68-76.

KANG, J. (2001): "Topic-comment Structure in English-Korean Simultaneous Interpretation", Conference Interpretation and Translation 3, p. 31-58.

KIM, H. (1996): "Study of Effective Korean-Japanese Simultaneous Interpretation", Collected Theses of the Graduate School of Interpretation, Hankuk University of Foreign Studies 5, p. 141-188.

KIM, H. (1999): "Chinese Characters in Korean-Japanese and Japanese-Korean Simultaneous Interpretation”, Collected Theses of the Graduate School of Interpretation, Hankuk University of Foreign Studies 3, p. 4978.

KIM, H. (2003): “A Study of Interference Caused by Cognate Signifiants in Korean-Chinese Translation”, Ph.D. thesis, Department of Chinese Language and Literature, Hankuk University of Foreign Studies.

KIM, H. (2003): “A Study of Cultures Using Chinese Characters and their Impact on Translation Studies", FORUM 1-1, p. 13-40.

KIM, H. (2004): "Strategy to Block Interference from the Source Language in Korean-Chinese Interpretation", Proceedings of the $4^{\text {th }}$ International Conference on Translation and Interpretation Studies, p.115-140.

KURZ, I. (2001): "Conference Interpreting: Quality in the Ears of the User", Meta 46-2, p. 394-409. 
LEE, C. (1997): "Influence of the Structural Difference in Arrangement of Information Between Korean and English on Simultaneous Interpretation", Collected Papers of the Interpretation and Translation Institute, Hankuk University of Foreign Studies 1, p. 1-22.

LEE, H. (1989): Introduction to Japanese Language Studies, Hanshin Munhwasa.

LEE, T. (2002): “Computer Analysis Tools for Time Aspects of Simultaneous Interpretation", Conference Interpretation and Translation 4-2, p. 113-134.

LEE, T. (2002): "Ear-voice Span in English into Korean Simultaneous Interpretation”, Meta 44-2, p. 596-606.

LEE, T. (2004): "Analysis of Paired Korean Simultaneous Interpretation for a Speech Given in English", Forum 2-2, p. 293-313.

LIM, H. (1999): "Evaluating Simultaneous Interpretation", Conference Interpretation and Translation, Inaugural issue, p. $145-162$.

LIM, H. (2002) : "Relay Interpretation: A Necessary Evil?”, Conference Interpretation and Translation 4-2, p. 149-172.

NAM, G. (2001): Syntactical Theory of Modern Korean, Taehaksa.

NORMAN, J. (1996): “Translated by Jeon Gwang-jin”, Introduction to Chinese Language Studies, Dongmunseon.

PÖchHACKer, F. (2001): “Quality Assessment in Conference and Community Interpreting”, Meta 46-2, p. 410425.

PARK, S. (1991): “The Topic in Korean in Regard to its Function in Discourse”, Grammar I, Taehaksa. 